\title{
Male's Level of Personal Well-Being and Anxiety Trait Regarding a Sport Activity Level
}

\author{
Petra Pacesova ${ }^{1}$, Pavel Smela ${ }^{1}$ and Branislav Antala ${ }^{1}$ \\ ${ }^{1}$ Comenius University, Faculty of Physical Education and Sport, Bratislava, Slovakia
}

\begin{abstract}
The aim of the paper is to identify the level of male's well-being and anxiety trait regarding their level of sport activity. The research group consists of 86 males ( $20.40 \pm 1.08$ years; $n$ : 29 recreational athletes, 21 elite athletes, 36 nonathletes). We used the BDP questionnaire to determine the level of male's wellbeing and STAI questionnaire to determine the level of anxiety trait. We used the Kolmogorov-Smirnov test to test the normality of the data and Kruskal-Wallis test, with post-hoc Mann-Whitney U-test to test the differences between the samples. We have noticed a difference in level of well-being as well as the anxiety trait. Pair comparison of groups have showed a significant difference in level of physical problems between recreational and elite athletes. We have also noticed a difference in the level of positive attitude towards life, self-esteem, and depressive mood between recreational athletes and nonathletes. Differences were also observed between elite athletes and nonathletes - in the level of both positive dimensions of well-being and in the level of physical problems and depressive mood as well. The difference in the level of anxiety trait was noticed only between recreational athletes and nonathletes.
\end{abstract}

Key words: well-being, anxiety trait, sport activity level, late adolescence, males

\section{Introduction}

Sports activities can be considered in broader and narrower contexts. The main themes in the narrower context of sports activities are human performance and competition. In the broader context, sports activities are important for reinforcing or improving health, physical appearance and coping strategies, as well as for physical movement per se (Fuchs, Klaperski, Gerber, \& Seelig, 2015).

In the present time, sports activity is seen as an important aspect of life from several points of view including health, regeneration, social relationships and as a feature of lifestyle. It is possible to distinguish multiple levels of sports activity - from the elite, high-performance level to the recreational level associated with leisure activities.

In our country, we distinguish "sport for all" and competitive and elite sport. The essence of sport for all is recreational activity involving various forms of physical exercise and other enjoyable physical activities. Competitive and elite sports focus on performance and involve activities defined by rules, skills developed in a training process and participation in competitions organised on a voluntary basis (Act No $28 / 2009$ on physical culture, as amended). Of course, recreational athletes can themselves be performance-oriented and may participate regularly in competitions.

The highest level of sport, elite sport, often leads to representing one's country and can provide a source of livelihood for the individual athlete. Elite athletes are individuals with the highest performance level in sport (Kučera \& Dylevský, 1994).

Sports activity on any level is linked to an individual's quality of life - sport is associated with quality of life both for active athletes and for ordinary people. The performance-level of sport that an individual participates in is often linked, amongst other things, to lifestyle, which affects quality of life (Stejskal \& Zusková, 2010).

The relationship between the concept of quality of life

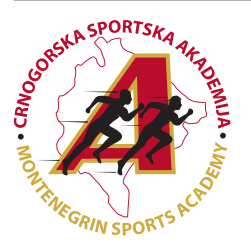

Correspondence:

P. Pacesova

Comenius University, Faculty of Physical Education and Sport, Bratislava, Slovakia

E-mail: petra.pacesova@uniba.sk 
and subjective personal wellbeing is an issue in several lines of research, one of which considers personal wellbeing as an indicator of a person's quality of life (Džuka, 2004). In this case, the concept of personal wellbeing can be considered a sub-category of the concept of quality of life that also functions as an indicator of its level.

Personal wellbeing is a persistent emotional state that is reflected in a person's overall satisfaction with their own life. A state of personal wellbeing can be expressed by varied emotional experience and cognitive content and therefore it is not considered a simple construct, but rather a broad and diverse category of psychological variables (Blatný et al., 2010).

Aspects of personal wellbeing can be seen as positive or negative depending on their content. Positive aspects include a positive outlook on life and an optimal level of self-evaluation (Džuka, 1995). The negative aspects of personal wellbeing are associated with concepts such as anxiousness and anxiety. Their link to personal wellbeing is evident because the symptoms of anxiety and depression are considered to have a negative influence on this construct. The differences in the content of these terms must be clarified because they are treated differently in research. Anxiety trait is a longer-lasting personality trait involving a stable, elevated tendency to experience uncertainty and to react with anxious behaviour (Vágnerová, 2004). This personality trait is mainly related to the individual's constitution and causes them to experience frequent and excessive states of anxiety (Matějček, 2011).

Other possible negative dimensions of personal wellbeing include aspects such as the individual's level of awareness of problems and their physical problems (Džuka, 1995).

The nature of these aspects of personal wellbeing and the content of the construct clearly indicate that personal wellbeing may be influenced by the benefits and other aspects of sport. At present there is a tendency to see sports as being linked to personal wellbeing a person's anxiety trait level, as has been demonstrated by many research findings (Aidar et al., 2018; Pačesová \& Šmela, 2018; Balatka, 2007).

In the context of previous findings, the aim of this study is to find out the differences in the level of individual aspects of wellbeing and anxiety trait of male elite athletes, recreational athletes and nonathletes in late adolescence.

\section{Methods}

The research sample comprised 86 men (mean age $19.94 \pm 1.38$ years). In terms of age, all respondents were in the period of late adolescence, although from a formal viewpoint, they could be considered adults. In the following text "adolescent" and "man" will therefore be used as synonyms. Respondents were categorised according to their level of participation in sport as recreational athletes $(n=29)$, elite athletes $(n=21)$ and nonathletes $(n=36)$.

Their level of personal of wellbeing was measured in several aspects (dimensions) using the Bern Questionnaire on Subjective Wellbeing (BSW) by Groba (1991). It was translated and adapted into Slovak by Džuka (1995).

The questionnaire consists of 28 questions covering several aspects of an individual's subjective wellbeing. The questionnaire implicitly works with three basic components of subjective wellbeing: habitual mental wellbeing, current mental wellbeing and current physical wellbeing (Džuka, 1995). Participants respond using a Likkert scale. The items in the que- stionnaire can be plotted in five dimensions (Džuka, 1995):

1. Positive attitude to life - items on the respondent's attitude to life events and the belief that one is leading a meaningful life.

2. Awareness of problems - items on the respondent's awareness of problems in their personal and social environment.

3. Physical problems and reactions - items measuring physical reactions and related problems.

4. Self-evaluation - items on the respondent's self-acceptance and their belief in their own value and ability to achieve goals.

5. Depressive mood - items where a high score indicates the absence of enjoyment and meaning in life.

Anxiety trait level was measured using the State-Trait Anxiety Inventory (STAI). The standard version of the inventory used in Slovakia is by Ruisel, Mullner, and Farkaš (1980). It is a questionnaire based on the assumption that there is a measurable difference between a temporary, transient state and a relatively permanent predisposition (Ruisel et al., 1980). The anxiety scale is designed to measure anxiety trait as a characteristic or tendency while respecting "individual differences in the tendency to perceive the world, the disposition to respond in a specific and predictable manner, individual differences in the expression of special emotional states and the positive correlation between the strength of personality and the intensity of the corresponding emotional state" (Ruisel et al., 1980). The anxiety scale is a whole number obtained by totalling the scale values (taking account of reversal scoring). The higher the score, the higher the level of anxiety trait. The possible score range is 20 to 80 .

Statistical tests of the data were conducted - a Kolmogorov-Smirnov test to test for normality of distribution, a Kruskal-Wallis test of variance between ranks and a post hoc Mann-Whitney U-test. Effect size was calculated using the coefficient $r$ ( $r \geq 0.9$ - very strong relationship; $r=0.7-0.9$ - strong relationship; $r=0.5-0.7$ - medium-strong relationship; $\mathrm{r}=0.3-0.5$ - weak; $\mathrm{r} \leq 0.3$ - very weak relation) (Pett, 1997) and coefficient $\eta 2$ (eta squared) ( $\eta 2 \geq 0.01$ - small effect, $\eta 2 \geq 0.06$ - medium effect, $\eta 2 \geq 0.14$ - strong effect (Cohen, 1988).

This study was approved in advance by the Ethics committee of the Faculty of physical education and sport, Comenius University (no. 1/2019).

\section{Results}

The results showed differences in the levels of the aspects of personal wellbeing depending on men's level of participation in sport during adolescence. Each aspect (dimension) of personal wellbeing was assessed individually.

There were significant differences between men with different levels of sports participation in the two positive aspects of personal wellbeing positive attitude towards life $[\mathrm{H}(2)=21.16, \mathrm{p}=0.00, \eta 2=0.26]$ and self-evaluation $[H(2)=15.67, p=0.00, \eta 2=0.17]$. Significant differences were also found in two negative aspects of personal wellbeing physical problems $[\mathrm{H}(2)=16.45, \mathrm{p}=0.00, \eta 2=0.20]$ and depressive $\operatorname{mood}[\mathrm{H}(2)=20.62, \mathrm{p}=0.00, \eta 2=0.24]$.

The remaining negative aspect of personal wellbeing awareness of problems - did not show significant differences between different levels of participation in sport $[\mathrm{H}(2)=1.81$, $\mathrm{p}=0.41, \eta 2=0.02]$. 
The analysis of the results also looked at differences in anxiety trait level between men who participated in sport on an elite level, on a recreational level or not at all. The results showed significant difference between men with a $5 \%$ thres- hold of statistical significance $[H(2)=6.63, p=0.04, \eta 2=0.05]$.

The specific values of the median and $\mathrm{p}$-value for each aspect of personal wellbeing at each level of men's participation in sport is shown in Table 1.

Table 1. Mean values of aspects of male's personal wellbeing regarding the sport activity level

\begin{tabular}{|c|c|c|c|c|}
\hline \multirow[b]{2}{*}{ Aspects of wellbeing } & \multicolumn{3}{|c|}{ Median \pm SD } & \multirow[b]{2}{*}{ p-value (KW) } \\
\hline & $\begin{array}{c}\text { Elite } \\
\text { athletes }\end{array}$ & $\begin{array}{c}\text { Recreational } \\
\text { athletes }\end{array}$ & Nonathletes & \\
\hline Positive attitude towards life & $4.56 \pm 0.57$ & $4.16 \pm 0.69$ & $3.73 \pm 0.84$ & $0.00^{* *}$ \\
\hline Awareness of problems & $2.29 \pm 0.78$ & $2.40 \pm 0.97$ & $2.88 \pm 0.68$ & 0.41 \\
\hline Physical problems & $1.65 \pm 0.72$ & $2.30 \pm 0.69$ & $2.54 \pm 0.71$ & $0.00^{* *}$ \\
\hline Selfevaluation & $4.44 \pm 0.93$ & $4.93 \pm 0.81$ & $3.94 \pm 1.00$ & $0.00^{* *}$ \\
\hline Depressive mood & $1.75 \pm 0.67$ & $1.91 \pm 0.69$ & $2.54 \pm 0.53$ & $0.00^{* *}$ \\
\hline Anxiety trait & $35 \pm 5.55$ & $32.00 \pm 8.70$ & $38.00 \pm 5.00$ & $0.04^{*}$ \\
\hline
\end{tabular}

Paired comparison of the groups of men based on their level of participation in sport for each dimension brought to light deeper information on the level of personal wellbeing in its several aspects. The only aspect of personal wellbeing to show differences between recreational athletes and elite athletes was physical problems $[\mathrm{U}=174.00, \mathrm{p}=0.01, \mathrm{r}=0.36]$. Recreational athletes scored $2.30 \pm 0.69$ whereas elite athletes had a significantly lower score $-1.65 \pm 0.72$ The differences in other aspects of personal wellbeing and in the level of anxiety trait were not statistically significant.

The comparison of men who participate in sport on a recreational level and men who do not participate in sport at all revealed more differences that were significant. There were differences in the level of both positive dimensions of personal wellbeing - positive attitude towards life [U=262.00, $\mathrm{p}=0.00, \mathrm{r}=0.43]$ and self-evaluation $[\mathrm{U}=233.00, \mathrm{p}=0.00$, $\mathrm{r}=0.48]$. In the level of positive attitude towards life, recreational athletes scored $4.16 \pm 0.69$ compared to nonathletes' score of $3.73 \pm 0.84$. Higher scores were also found in the case of self-evaluation - recreational athletes scored $4.44 \pm 0.93$ whereas nonathletes had $3.94 \pm 1.00$

Of all the negative aspects of personal wellbeing, there was a significant difference in only one - depressive mood $[\mathrm{U}=268.50, \mathrm{p}=0.00, \mathrm{r}=0.42]$. Recreational athletes had a score of $1.91 \pm 0.69$ whereas nonathletes scored significantly higher $-2.54 \pm 0.53$. There was also a significant difference in the level of anxiety trait $[\mathrm{U}=332.50, \mathrm{p}=0.00, \mathrm{r}=0.31]$. A higher level of anxiety trait was found in nonathletes $(38.00 \pm 5.00)$ than in recreational athletes $(32.00 \pm 8.70)$.

Differences in the level of individual aspects of personal wellbeing and anxiety trait were also compared for elite athletes and nonathletes. This produced several interesting significant differences. There were differences in the level of both positive dimensions of personal wellbeing - positive attitude towards life $[\mathrm{U}=131.50, \mathrm{p}=0.00, \mathrm{r}=0.54]$ and seIf-evaluation [ $\mathrm{U}=233.00, \mathrm{p}=0.02, \mathrm{r}=0.32$ ]. The results show that elite athletes have higher levels of the positive aspects of personal wellbeing. Their level of positive attitude to life reached $4.56 \pm 0.57$, while nonathletes' level was significantly lower $-3.73 \pm 0.84$. In self-evaluation, elite athletes' level was $4.44 \pm 0.93$, and, again, nonathletes' level was significantly lower $-3.94 \pm 1.00$.

As regards the negative aspects of personal wellbeing, there was a significant difference in the level of physical problems $[\mathrm{U}=140.00, \mathrm{p}=0.00, \mathrm{r}=0.53]$. Elite athletes had lower levels in this dimension of personal wellbeing than nonathletes $-1.65 \pm 0.72$ compared to $2.54 \pm 0.71$ respectively.

There was also a significant difference in the level of depressive $\operatorname{mood}[\mathrm{U}=132.00, \mathrm{p}=0.00, \mathrm{r}=0.55]$. Elite athletes had a lower level of depressive mood $(1.75 \pm 0.67)$ than nonathletes $(2.54 \pm 0.53)$. No significant differences were found between elite athletes and nonathletes in the level of awareness of problems or in the anxiety trait.

The differences in individual aspects of personal wellbeing and anxiety trait between the different levels of men's participation in sports are set out in Table 2.

Table 2. Differences in the level of male's personal wellbeing aspects and anxiety trait regarding the sport activity level

\begin{tabular}{ccccccc}
\hline & \multicolumn{2}{c}{$\mathbf{p}$-value (MW) } & & & Physical \\
\hline $\begin{array}{c}\text { Physical activity } \\
\text { level }\end{array}$ & $\begin{array}{c}\text { Positive attitude } \\
\text { towards life }\end{array}$ & $\begin{array}{c}\text { Awareness } \\
\text { problems }\end{array}$ & $\begin{array}{c}\text { Phoblems } \\
\text { probevaluation }\end{array}$ & $\begin{array}{c}\text { Depressive } \\
\text { mood }\end{array}$ & $\begin{array}{c}\text { Anxiety } \\
\text { trait }\end{array}$ \\
\hline $\begin{array}{c}\text { Recreational ath. } \\
\text { Elite ath. }\end{array}$ & 0.18 & 0.66 & $0.01^{* *}$ & 0.28 & 0.27 & 0.17 \\
$\begin{array}{c}\text { Recreational ath. } \\
\text { nonathletes } \\
\text { Elite ath. }\end{array}$ & $0.00^{* *}$ & 0.46 & 0.10 & $0.00^{* *}$ & $0.00^{* *}$ & $0.01^{* * *}$ \\
nonathletes & $0.00^{* *}$ & 0.16 & $0.00^{* *}$ & $0.02^{*}$ & $0.00^{* *}$ & 0.28 \\
\hline
\end{tabular}

\section{Discussion}

The relationship between level of participation in sport and personal wellbeing has not yet been adequately researched, with research tending to focus on the effect of sports activity itself on the level of personal wellbeing. Moreover, the evidence base regarding the mental health and wellbeing of elite athletes is limited by a paucity of high-quality, systematic studies (Rice et al., 2016).

The findings of the present research suggest that level of participation in sport may be a variable that is linked to young men's personal wellbeing during adolescence. The findings suggest that the levels of positive aspects of personal wellbe- 
ing - positive attitude towards life and self-evaluation - are significantly lower in men who do not participate in sport compared to men who participate in sport on a recreational or elite level. No difference was found between recreational and elite athletes in positive aspects of personal wellbeing, and we can thus conclude that regular sports activity helps to increase the level of positive aspects of personal wellbeing. Similar findings of increased levels in positive aspects of personal wellbeing resulting from participation in sports were reported by Penedo and Dahn (2005), and McAuley and Rudolph (1995).

Although the present research did not find significant differences between recreational and elite athletes in the levels of the positive aspects of personal wellbeing, there is reason to believe that each level of sports activity is affected by different variables. Cronin and Allen (2018) have demonstrated that elite athletes' level of personal wellbeing is related to "life skills" like teamwork, goal setting, time management, emotional skills, interpersonal communication, social skills, leadership, problem solving and decision making. The interpretation of the results indicates that a trainer's support for such skills can increase elite athletes' level of personal wellbeing.

On the other hand, Rice et al. (2016) showed that the risk of mental disorders such as anxiety or depression in elite athletes was comparable to that in the general population. The population of elite athletes is sensitive to a range of mental health problems (including substance abuse) that may be linked to sports factors (e.g. injury, burnout) as well as factors that have nothing to do with sport and a significant effect on wellbeing.

The results on negative aspects of personal wellbeing are unclear. Although levels were lowest in nonathletes, the differences were not always statistically significant.

As regards level of physical problems, it can be said that the lowest level was found in elite athletes. This result may appear paradoxical, but it may be due to the fact that the research population is made up of men who are still young, and elite level sports can be expected to provide a certain standard of health care. Study of the motivation for recreational athletes' participation in sports would benefit the picture of this aspect of personal wellbeing.

The level of depressive mood was found to be highest in nonathletes compared with athletes at any level of participation. This finding reinforces the findings on nonathletes' low levels in positive aspects of personal wellbeing. The same applies to anxiety levels - a substantial body of literature has shown that sports activity reduces symptoms of both anxiousness / state anxiety (Hassmén, Koivula \& Uutela, 2000) and trait anxiety (Aidar et al., 2018). These findings add to the evidence of sports' benefits for people's mental health. The present research found the highest anxiety trait level in nonathletes and the lowest in recreational athletes.

The highest levels of the positive aspects of personal wellbeing are found in men who participate in sport on a recreational or elite level. A further conclusion is that any level of participation in sport increases men's experience of positive aspects of personal wellbeing. The lowest levels of negative aspects were found in men who did not participate in sport. Since there are many factors that could affect the personal wellbeing of men who participate in sport on a recreational or elite level, more detailed research is needed on this aspect of the issue.
Acknowledgements

This study was supported through a Scientific Grant Agency of the Ministry of Education of Slovak Republic Vega 1/0726/17.

\section{Conflict of Interest}

The authors declare that there are no conflicts of interest.

Received: 13 March 2019| Accepted: 04 May 2019| Published: 01 June 2019

\section{References}

Aidar, F.J., Jacó de Oliveira, R., Gama de Matos, D., Chilibeck, P.D., de Souza, R.F., Carneiro, A.L., \& Machado Reis, V. (2018). A randomized trial of the effects of an aquatic exercise program on depression, anxiety levels, and functional capacity of people who suffered an ischemic stroke. Journal of Sports Medicine \& Physical Fitness, 7-8, 1171-1177.

Balatka, O., (2007). The influence of physical activities on quality of life in regions [Vliv pohybových aktivit na kvalitu života $v$ regionech]. In V. Hošek a P. Tiliger (Eds). Psychosocial functions of physical activities as a part of adult quality of life [Psychosociální funkce pohybových aktivit jako součást kvality života dospělých]. 94-117. Praha: Univerzita Karlova, FTVS.

Blatný, M., Hřebíčková, M., Millová, K., Plháková, A., Říčan, P., Slezáčková, A., \& Stuchlíková, I. (2010). Personality psychology: main topics, contemporary approaches [Psychologie osobnosti: hlavní témata, současné prístupy]. Praha, Grada.

Cohen, J. (1988). Statistical power analysis for the behavioral sciences. Hillsdale $\mathrm{NJ}$ : Erlbaum Associates.

Cronin, L.D., \& Allen, J. (2018). Examining the relationships among the coaching climate, life skills development and well-being in sport. International Journal of Sports Science and Coaching, 13(6), 815-827.

Džuka, J., (2004). Quality of life and subjective well-being - theory and models, similarities and differences [Kvalita života a subjektívna pohoda - teórie a modely, podobnost' a rozdiely]. In: J. Ďžuka (Ed). Psychological dimensions of quality of life [Psychologické dimenzie kvality života]. Prešov: Prešovská Univerzita.

Džuka, J. (1995). Factor analysis of the modified version of the Berne questionnaire of subjective well-being [Faktorová analýza modifikovanej verzie Bernského dotazníka subjektívnej pohody (BDP)]. Československá psychologie, 39(6), 512-522.

Fuchs, R., Klaperski, S., Gerber, M., \& Seelig, H. (2015). Measurement of movement and sports activity: The BSA questionnaire: A methodical balance sheet [Messung der Bewegungs und Sportaktivität: Der BSA- Fragebogen: Eine methodische Zwischenbilanz]. Zeitschrift für Gesundheitpsychologie, 23(2), 60-76.

Hassmén, P., Koivula, N., \& Uutela, A. (2000). Physical excercise and Psychological Well-Being: A population Study in Finland. Preventive Medicine, 30(1), $17-25$.

Kučera, M., \& Dylevský, I. (1999). Sport Medicine [Sportovní medicína]. Praha: Grada.

Matějček, Z. (2011). Praxe dětského psychologického poradenství. Praha: Portál.

McAuley, E. \& Rudolph, D. (1995). Physical Activity, Aging, and Psychological Well-Being. Journal of Aging and Physical Activity, 3(1), 67-96.

Pačesová, P., \& Šmela, P. (2018). Personal well-being as part of the quality of life: Is there a difference in the level of personal well-being of men regarding their sport activity? [Osobná pohoda ako súčast' kvality života: liši sa subjektívna osobná pohoda mužov na základe ich športovej aktivity?] In Baisová, K. A Kružliak, M. (Eds.) Physical Education and Sport in Human Life: Conference textbook of scientific papers [Telesná výchova a šport v živote človeka: konferenčný recenzovaný zborník vedeckých prác]. Zvolen: Vydavatel'stvo Technickej univerzity.

Penedo, F.J., \& Dahn, J.R. (2005). Exercise and well-being: a review of mental and physical health benefits associated with physical activity. Current Opinion in Psychiatry, 18(2), 189-193.

Pett, M.A. (1997). Nonparametric statistics for health care research: Statistics for small samples and unusual distributions: Sage.

Rice, S.M., Purcell, R., DeSilva, S., Mawren, D., McGorry, P.D., \& Parker, A.G. (2016). The Mental Health of Elite Athletes: A Narrative Systematic Review. Sports Medicine, 46(9), 1333-1353.

Ruisel, I., Mullner, J., \& Farkaš, G. (1980). Anxiety state and Anxiety trait Questionnaire: manual [Dotazník na meranie úzkosti a úzkostlivosti: príručka]. Bratislava: Psychodiagnostika, s.r.o.

Stejskal, T. \& Zusková, K. (2010). Training Process and Athlete Adaptability: Training Process as a Stressor [Tréningový proces a adaptabilita športovca: Tréningový proces ako stresor]. In Zusková, K. a kol. Athlete's personality from the perspective of selected areas of psychology and sport [Osobnost' športovca z pohladu vybraných oblastí psychológie a športu]. Prešov: Prešovská univerzita v Prešove.

Vágnerová, M. (2004). Basics of Psychology [Základy psychologie]. Praha: Karolinum. 